\title{
ODNOS VJERE I POLITIKE U PERCEPCIJI ISLAMISTA I SEKULARISTA ${ }^{2}$
}

\section{SAŽETAK}

Cilj ove studije je istražiti i rasvijetliti odnos između vjere $i$ politike s aspekta islama i sekularizma. Opće mišljenje koje vlada među elitom i narodom, jeste da su ove dvije društvene kategorije isključive $i$ da ih je nemoguće ukalkulisati u jedan mehanizam (društvo) u kome bi uzajamno djelovale i davale pozitivne rezultate $i$ korisna ishodišta. Studija je nakon podrobnih istraživanja dokazala da je konvencionalna vizija odnosa predmetnih društvenih kategorija paušalna i netačna, a da je suprotna teza tačna. U konačnici, studija je došla do zaključka da su islam i politika nerazdvojne društvene dimenzije, jer je nemoguće islam živjeti bez politike a ni pravu politiku primijeniti i voditi bez istinske vjere.

Ključne riječi: islam, politički islam, politike, modernisti, modernizam, sekularisti, sekularizam, šerijatska politika, vjera.

\section{Uvod}

Vjera je, po najjednostavnijoj definiciji, sve ono što ljudi poštuju, po čijim kriterijima se ravnaju i u što vjeruju, bez obzira da li je to ispravno ili neispravno. Ova konstatacija se može potvrditi i sljedećim kur'anskim ajetima: $O$ sljedbenici Knjige, ne zastranjujte $u$ svome vjerovanju. (En-Nisa: 171) A vama - vaša vjera, a meni moja! (El-Kafirun: 6)

Ako se u Kur'anu tematski prouči značenje riječ vjera (ed-din), zapazit će se da ona ima različita značenja koja određuje sami kontekst u kome se našla.

\footnotetext{
${ }^{1}$ Islamski pedagoški fakultet u Bihaću

2 Ovaj rad je naslonjen i koncipiran na studiju Jusufa el-Karadavija objavljenu u njegovom djelu Ed-Dinu vessijasetu, t'esilun ve reddu šubehatin, min isdarati, ElMedžlisul-eurubijju lil-iftai vel-buhusi.
} 
Tako, ponekad, ima značenje nagrade kao što je u suri El-Fatiha (4. ajet), ponekad pokornosti kao što je u suri En-Nisa (164. ajet), zatim temelja vjere $i$ vjerske doktrine kao što je u suri Eš-Šura (13. ajet), a često i vjerovanja u kojeg vjeruje neki narod, pa makar ono bilo i neispravno.

\section{Vjera $\mathrm{i}$ islam}

Tematskim proučavanjem riječi vjera $i$ islam u Kur'anu, zapaža se kako riječ islam ima šire značenje od pojma vjere. Riječ vjera (eddin) može imati isto značenje kao i riječ islam ako joj se pridoda, ili ako se pridoda Allahu, kao npr., vjera islam ili Allahova vjera. Međutim, ako se riječ vjera upotrebljava samostalno, onda ona, bez sumnje, ima uže značenje od pojma islam. Islam označava vjeru i ovaj svijet, vjerovanje i vjerozakon, obred i ophođenje, misiju i državu, moral i snagu. Dok vjera ili religija označava i definira samo vezu između Boga i čovjeka.

\section{Definicija politike (es-sijase) i njena upotreba u islamskoj kulturnoj baštini}

Politika se najčešće definira kao umjetnost upravljanja poslovima i problemima ljudi, odnosno kao umijeće upravljanja ljudskim zajednicama. ${ }^{3}$

Treba istaći da riječ politika (es-sijase) nije spomenuta ni u mekanskoj, ni u medinskoj objavi. Ovu činjenicu su neki uzeli kao dokaz za svoj stav da se Kur'an, pa ni islam, ne zanimaju za politiku. Međutim, takvo razumijevanje Kur'ana i islama je apsolutno pogrešno, jer je moguće da se neka riječi ili termini eksplicitno ne spomenu $u$ Kur'anu, ali su njihova značenje involvirana u značenjima Kur'ana, ili se na njih aludira na jedan od kur'anskih načina, preko kojih Kur'an ukazuje na značenja, norme i propise.

Npr., riječ vjerovanje (el-'akide), također, eksplicitno nije spomenuta u Kur'anu, ali i pored toga, njena značenja su prisutna u cijelom Kur'anu. Isto tako i riječ dobro (el-fadile) nije spomenuta u

\footnotetext{
${ }^{3}$ Vidi: Džami'atul-Kuvejt, Mevsu'atul-'ulumis-sijasijjeti, Poglavlje 78., str.102. 
Kur'anu, ali i pored toga Kur'an od početka do kraja podstiče ljude na činjenje dobra i odvraćanje od zla.

Jednako pravilo važi i za riječ politika (es-sijase). I pored toga što nije eksplicitno spomenuta u Kur'anu, ipak Kur'an sadržava riječi koje aludiraju na nju, i detektiraju njena značenja poput riječi: vlast (el-mulk, En-Nisa: 54, El-Bekare: 247); snaga i moć (et-temkin, Jusuf: 56, El-Hadždž: 41); nasljeđivanje (el-istihlaf, En-Nur: 55, El-'Araf: 129); suđenje i vladanje (el-hukm, El-Maide, 44, 45, 47, 50) itd.

No, takav slučaj nije sa sunnetom. U njemu postoji jedan hadis $\mathrm{u}$ kom je upotrijebljena izvedenica iz riječi politika. Hadis je vjerodostojan i prenosi ga Ebu-Hurejre. Između ostalog, u njemu se veli kako su Israilićane vodili poslanici i kad god bi jedan od njih umro, Allah bi im poslao drugog.

U Kuvajtskoj pravnoj enciklopediji pod naslovom Politika (Essijase) stoji: Čini se da je najstariji tekst u kom se riječ politika (essijase) upotrebljava u značenju vlasti - tekst, tj., govor Amr b. Asa upućen Musau el-Eš'ariju u kom opisuje Muaviju na sljedeći način: 'Ja smatram da on može biti nasljednik Osmana, halife kome je nepravda učinjena. On traži osvetu za njegovu krv, lijepe je politike $i$ dobrog rezonovanja. ${ }^{5}$

Ova tvrdnja bi se mogla prihvatiti kada se misli na korijen riječi politika. Međutim, ako se misli na njene izvedenice, onda ta konstatacija nije tačna i ne može se uvažiti, jer je demantira navedeni hadis kojeg prenosi Ebu-Hurejre kao i predaja koju prenosi Ebu-Šejba u svom Musannefu i Hakim u svom Mustedreku, od Mustezilla b. Husajna da je rekao: Omer b. el-Hattab nam je održao hutbu i između ostalog rekao: 'Tako mi Gospodara Kjabe, shvatio sam kada će biti uništeni Arapi.' Neko od muslimana je ustao i upitao: 'Kada, vođo pravovjernih?' 'Kada vođstvo nad njima preuzmu oni koji se nisu

4 Bilježi ga Buharija u Poslanicima (3455), Muslim u Imaretu (1842) od EbiHurejre, Ahmed u Musnedu (79600) i Ibn-Madže u Džihadu (2871).

5 Vizaretul-Evkafi veššu'unil-islamijjeti, El-Mevsu'atul-fikhijjetul-kuvejtijje, EtTab'atur-rabi'atu, 1414. H. -1993. god., 25/295-296. 
borili protiv džahilijjeta, niti su se družili sa Poslanikom, odgovorio $j e^{16}$

Islamski pravnici su u različitim prilikama govorili o politici, a posebno kada se radilo o diskrecionoj kazni (et-t'azir) tj., sankciji koja nije definirana pravnim tekstom.

Neki su šerijatskoj politici davali mnogo prostora u pravnim izvorima, dok su je drugi ignorirali i bili malo suzdržaniji prema njoj. Čini se da su šafijski pravnici najmanje pribjegavali institucije šerijatske politike, radi toga što ne priznaju pomoćni pravni izvor opći interes (el-maslehatul-mursele). Hanefijski i hanbelijski pravnici su pribjegavali instituciji šerijatske politike više od šafijskih pravnika, a malikijski su je opet najviše od svih koristili. ${ }^{7}$

\section{Uloga Ibnul-Kajjima u definiranju pojašnjenju pojma šerijatska politika}

Ibnul-Kajjim je, bez sumnje, bio jedinstven u historiji islamske misli. Temeljito i detaljno je govorio o politici. Na najljepši ju je način objasnio, otkrio njena značenja, pojasnio razliku između pravedne i nepravedne politike i rekao da je prva dio Šerijata i da ni u kome slučaju ne izlazi iz njegovih granica.

Sva svoja razmišljanja i studije o šerijatsko-pravnoj politici zabilježio je u svoja dva djela - 'Ilamul-muvekki'ine i Et-Turukulhukmijje. Pored ostalog, pojašnjavajući pojam šerijatske politike, kazao je kako je Ibn-Akil rekao da je politika postupak putem koga se ljudi približavaju dobru a udaljavaju od zla, i pored toga što ga Poslanik, a. s., nije radio a niti je o njemu objavljena objava.

Šafija je rekao da je politika samo ono što je kompatibilno sa Šerijatom. Ako se pod onim što je u skladu sa Šerijatom misli na to, da nije oprečno onome o čemu je Šerijat bio eksplicitan, onda je takvo poimanje politike ispravno. No, ako se misli samo na ono o čemu se Šerijat jasno izjasnio, onda je takvo poimanje politike pogrešno i suprotno njenom poimanju od strane ashaba. Npr., četverica halifa su

\footnotetext{
${ }^{6}$ Ebu-Šejbe, El-Musannef, 6/410, od Mustezilla b. Husajna, Hakim El-Mustedrek, 4/475, i veli da je ovaj hadis vjerodostojan, ali ga Buharija i Muslim nisu zabilježili. Zehebi se slaže s njegovom ocjenom, i El-Bejheki, Ěs- $\breve{S} u^{\prime} a b, 6 / 69$.

${ }^{7}$ Vidi: Karadavi, Ed-Dinu ves-sijasetu, str. 20-30.
} 
ubijali i mrcvarili na način kojeg ne negiraju eksperti hadisa. Dovoljno je navesti samo spaljivanje mushafa ${ }^{8}$ od strane Osmana, r. a. Takav stav je donesen na osnovu općeg interesa. Isto tako, Omer je protjerao Nasra b. Hadždžadža a Alija spalio odmetnike.

Potom se Ibnul-Kajjim osvrnuo i rekao: Ovo mjesto, tj., šerijatska politika je klizavo za stopala, zavodljivo za umove, neugodan stepen i teško raskršće.

Neki su u njemu pretjerali pa su anulirali 'fiksne kazne' (elhudud), zanemarili prava, i na taj način ohrabrili zlikovce na činjenje nereda. Učinili su Šerijat nemoćnim realizirati interese ljudi $i$ potrebnim za druge zakone. Zatvorili su pred sobom ispravne puteve spoznaje istine $i$ njene primjene. Tako su eliminirali istinu $i$ pored toga što su apsolutno oni $i$ drugi bili svjesni da je istina kompatibilna s realnošću. Međutim, smatrali su da je ona oprečna sa šerijatskim pravilima. A tako mi Allaha, ona nije oprečna onome sa čime je došao Poslanik, $i$ pored toga što negira ono što su razumjeli putem svoga idžtihada od Njegova vjerozakona. A do toga su doveli sljedeći razlozi:

1. nepotpuno poznavanje Šerijata,

2. nepotpuno poznavanje stvarnosti, $i$

3. tumačenje jedne stvari prema drugoj.

Nakon što su nadležni uvidjeli te stvari i uvjerili se da ljude može popraviti samo suprotno poimanje Šerijata oficijelnome poimanju, izumili su za svoju politiku veliko zlo $i$ široki nered. Situacija se nakon toga pogoršala i bilo ju je nemoguće obuzdati. Ulemi je zbog toga bilo teško osloboditi duše od tog zla i spasiti ih od te propasti.

Nasuprot prvoj grupi, druga grupa je dozvolila na tom polju stvari koje su oprečne Allahovom propisu i propisu Njegovoga Poslanika. Obje grupe su došle s nepotpunom spoznajom onoga sa

\footnotetext{
${ }^{8}$ To se desilo kada su neki ashabi u svojim privatnim zbirkama mushafa dodali i tumačenje nekih riječi. Potom su učači (karije) počeli širiti te mushafe. Neki od njih nisu bili u stanju da naprave razliku između tumačenja i tumačenog. Zbog toga je Osman sakupio sve takve mushafe i uz saglasnost ashaba ih sve spalio, a zatim napisao jedan službeni mushaf i obavezao ljude da njega koriste i šire.
} 
čime je poslan Allahov Poslanik i zbog čega je objavljena Njegova knjiga. Uzvišeni Allah je slao Svoje poslanike $i$ objavljivao Svoje knjige kako bi ljudi uspostavili pravdu na Zemlji. To je pravda na kojoj počivaju Zemlja i nebesa. Pa ako se na bilo koji način detektuju znakovi pravde $i$ otkrije njena bit, tu je u stvari Allahov vjerozakon $i$ Njegova vjera. Uzvišeni Allah je znaniji $i$ mudriji od toga da specificira puteve pravde i njene znakove i obilježja na neke stvari, a da potom zanemari one koji su jasniji od njih, jačega dokaza i očitijeg obilježja, da im ne da njihov status i da ne dozvoli presudu na osnovu njih. Naprotiv, Uzvišeni je objelodanio da je cilj metoda, koji je propisao, uspostava pravde među Njegovim robovima, kako bi živjeli po pravdi. Prema tome, svaki način i metod putem kojeg se dolazi do pravde i pravičnosti je od vjere i nije joj oprečan. ${ }^{9}$

Ovdje je Ibnul-Kajjim potpuno u pravu, jer manjkavost nije u Šerijatu, nego u onima koji zatvaraju ljudima sva vrata interesa i koristi, koji ne uzimaju u obzir intencije Šerijata i posljedice djela, niti balansiraju između štete i koristi, te ne uvažavaju prioritete. Na taj način sužavaju ljudima ono, što im je Allah ostavio širokim i zbog svoga lošega poimanja, tvrdoglavosti i konzervativnosti uništavaju ummetu mnoge interese.

Nasuprot njih, imamo one koji se ne zaustavljaju kod Allahovih granica, niti se ograničavaju s tekstovima Kur'ana i sunneta. U naše vrijeme ih ima mnogo. Oni nadležnima uljepšavaju i odobravaju ono što im se dopada i šta žele, te im na taj način dozvoljavaju da Šerijat $u$ njihovim rukama bude mehak kao tijesto koje nakon toga, po svojim hirovima i ćeifovima, oblikuju kako žele.

\section{Pravedna politika je kompatibilna sa eksplicitnostima Šerijata}

Potom je Ibnul-Kajjim rekao da se ne može tvrditi kako je pravedna politika oprečna onome što je eksplicitno u Šerijatu, nego je kompatibilna s njim i jedna je od njegovih neodvojivih dijelova. Mi je nazivamo politikom prema vašim terminima, a ona je u stvari samo Allahova pravda i pravda Njegovoga Poslanika koja se pojavila sa

\footnotetext{
${ }^{9}$ Vidi: Ibnul-Kajjim, Et-Turukul-hukmijje, tab'atul-mektebetil-islamijjeti, Bejrut, str. 42-43, 'Ilamul-muvekki'ine, matbe'atu-se'ade, misr, bi tahkik: Muhammed Muhjuddin Abdulhamid, 4/372-373.
} 
ovim znakovima i obilježjima. Poslanik, a. s., je zbog sumnje zatvarao optužene, a i kažnjavao ${ }^{10}$ bi ih, ako bi se na njima pokazali znakovi sumnje i krivnje.

A onaj ko pusti optuženog na slobodu i pored toga što zna da čini nered po Zemlji i što je poznat po krađi, tvrdeći da ga ne može zadržati bez svjedočenja dva pravedna svjedoka, njegova tvrdnja je oprečna šerijatskoj politici a postupak pogrešan.

Poslanik je npr., zabranio pravo na ratni plijen onome koji ga bez dozvole uzme prije njegove podjele. Takvom bi Poslanik, a. s., i njegovi zamjenici, pravedne halife, spaljivali sve stvari. ${ }^{11}$ Poslanik, a. s., je htio spaliti kuće onima koji ne bi klanjali džumu-namaz i koji bi zanemarivali obavezne namaze $\mathrm{u}$ džematu. ${ }^{12}$ Onome koji ne bi dao zekjat govorio je: Uzé́emo ga od njega i još njegova pola imetka. ${ }^{13}$ Isto je tako naredio nekoj ženi, koja je proklela svoju devu, da je pusti. $^{14}$

Istom metodom su se za Poslanikom, a. s., poveli i njegovi ashabi na čelu sa četvericom pravednih halifa. Tako je Ebu-Bekr, r. a., spalio homoseksualce i na taj način im dao priliku da okuse žestinu vatre na ovome svijetu prije onoga. Omer, r. a., je spalio točionice alkohola i sve ono što je bilo u njima. Isto je tako spalio i dvorac S'ad b. ebi-Vekkasa zbog toga što se zatvorio u njega i nije primao narod.

\footnotetext{
10 "Poslanik, a.s., je zatvorio nekog čovjeka radi sumnje."Bilježi ga Ahmed u Musnedu, (20019), od Muavije b. Hajjide, a njegovi verifikatori vele da mu je lanac prenosilaca dobar, Ebu-Davud u Sudstvu (3630), Tirmizi u Krvarinama (1417), i veli da je hasen, Nesai u Odsijecanju kradljivcu ruke (4875), Hakim u Mustedreku, 4/114 i veli da je vjerodostojan u čemu ga podržava i Zehebi.

${ }^{11}$ Ovdje se misli na hadis: Kada nađete da je čovjek ukrao dio ratnog plijena spalite mu stvari i kaznite ga. Bilježi ga Ebu-Davud u Džihadu (2713) od Omera, Tirmizi u Hududima (1461),+ i veli da je garib, Hakim u Mustedreku, 2/138, i veli da je sahih u čemu ga je i podržao i Zehebi, Bejheki, Es-Sunenul-kubra, 9/102 i rekao da je slab hadis, i Ebu-J'ala u Musnedu, 1/180.

${ }^{12}$ Aludira se na hadis koji bilježi Buharija u Konfliktima (2420) od Ebi Hurejre, i Muslim u poglavlju $O$ džamijama (651).

13 Bilježi ga Ahmed u Musnedu (200539) od Muavije b. Hajjeda. Njegovi verifikatori vele da je dobar, Ebu-Davud u Zekjatu (1575), Nesai u Zekjatu (2444), Hakim u Mustedreku (1/554) i veli da ispunjava uvjete Buharije i Muslima ali ga nisu uvrstili u svoje zbirke.

${ }^{14}$ Aludira se na hadis kog bilježi Muslim u Dobročinstvu i održavanju rodbinske veze (53).
} 
Osman, r. a., je okupio ljude oko jednog harfa, od sedam harfova na kojima je Kur'an objavljen, radi općeg interesa i jedinstva muslimana. Također je Alija, r. a., spalio otpadnike i ateiste, i pored toga što je znao kakva je kazna za njih u islamu propisana. Međutim, pošto je vidio da je u njegovo vrijeme otpadništvo i ateizam uzelo maha, povećao je kaznu za počinioce takvih delikata, da bi odvratio ljude od tog opasnog trenda.

\section{Fleksibilnost šerijatske politike i mogućnosti njena evaluiranja}

Nakon svega navedenog Ibnul-Kajjim je rekao: Cilj je da se potcrta $i$ istakne da spomenuti $i$ slični primjeri spadaju u domen partikularne (promjenljive) politike koja se, prema općem interesu, mijenja s promjenom vremena. Međutim, neki takvu politiku smatraju univerzalnom i obaveznom za islamski ummet sve do Sudnjega dana. Svako od njih za svoj stav ima opravdanje i nagradu, jer ko idžtihadi u okviru granica koje je postavio Allah i Njegov Poslanik, on se u stvari kreće između jedne $i$ dvije nagrade. Ova politika, kojom su prethodnici vodili ummet $i$ osnažili ga, produkt je tumačenja $i$ poimanja Kur'ana i sunneta. Međutim, postavlja se pitanje da li se ona smatra generalnim Šerijatom na kojega vrijeme ne utječe, ili je to partikularna politika koja slijedi interese, i koja se ograničava na njima $u$ okviru određenog vremena i prostora? ${ }^{15}$

Ovakva vrsta politike je bez sumnje partikularna politika koju nalažu interesi vremena, prostora $i$ situacije $u$ kojima se ona primjenjuje. U skladu s tim, kada se promijeni vrijeme, mjesto ili stanje, dužnost (vadžib) je da se izvrši i revizija starih propisa u svjetlu novonastalih prilika. Potom je neophodno da se politika promijeni ili revidira prema novonastalim prilikama i interesima, a nije dozvoljeno da se konzervira na starim propisima, pod izgovorom da se danas neko pitanje ne može bolje riješiti, nego što je već prije riješeno, jer realnost nam govori suprotno. Danas je čovjek u mogućnosti učiniti mnogo više nego prije, pod uvjetom da se kod njega nađu znanje i volja, a posebno s obzirom na ogroman napredak nauke koja je podarila čovjeku snagu i ogromne intelektualne, materijalne i druge mogućnosti o kojima je prije samo sanjao i maštao.

15 Vidi: Ibnul-Kajjim, Et-Turukul-hukmijje, str. 41-50., Ibnul-Kajjim, 'Ilamulmuvekki'ine, 4/372-375. 


\section{Termin politika kod islamskih pravnika}

Dosadašnja uvodna elaboriranja odnosila su se na stav islamskih pravnika oko pitanja termina politika; na definiranje njenoga značenja i njihovom pogledu na tu granu islamskog prava, gdje se vidjelo da joj neki proširuju polje djelovanja, dok ga drugi svode na minimum. Međutim, ako se na politiku osvrnemo s aspekta njene biti i suštine, tj., da je ona umijeće upravljanja narodom i realizacija narodnih prava, emaneta, itd., zapazit ćemo da su islamski pravnici o tome mnogo više govorili i raspravljali.

Neki su te rasprave inkorporirali u sama pravna djela pod poznata poglavlja poput: Imameta (Vođstva), Kada'a (Sudstva), Hududa (Fiksnih kazni), Džihada (Borbe) itd., dok su drugi o tome pisali posebna djela u kojima su se zanimali za teme iz oblasti: vlasti, politike, administracije, imetka, itd. Od njih možemo navesti sljedeća: El-Ahkamus-sultanijje od Ebul-Hasana El-Maverdija, šafijskog pravnika (umro 450. H.), kao i djelo sa istim naslovom od Ebu-J'ale el-Fera'e el-Hanbelija (umro 456. H.), El-Gijasi od imama dva hrama El-Džuvejnija (umro 476. H.), Es-Sijasetuš-šer'ijjetu od Ibn Tejmijje (umro728. H.), Et-Turukul-hukmijje od Ibnul-Kajjima. Tebsiretulhukkami od Ibn-Ferhuna (umro 799. H.), Tahrirul-hukkami od IbnDžema'ah. Mu'inul-hukkami od Tarablisija (umro 644. H.), kao i sva ostala djela islamskih klasika koja su napisana s namjerom da budu izvori islamskog sudstva i vlasti.

U islamskoj pravnoj baštini postoje i djela koja su specificirana samo za imovinsku politiku poput El-Haradža od Ebu-Jusufa, najvećeg Ebu-Hanifina učenika, kojeg je napisao za Haruna Rešidu, da po njemu vodi imovinsku politiku. Isto tako El-Haradž od Jahje b. Adema (umro 203. H.), El-Emval od Ebi-Ubejda el-Kasima b. Abdusselama (umro 224. H.). Ovo je djelo najveličanstvenije od napisanih o imovinskom pravu u islamu. El-Emval od IbnZandževejha (umro 248. H.), El-Istihradž fi ahkamil-haradži od IbnRedžeba el-Hanbelija.

Mnogi su islamski učenjaci pisali o šerijatskoj politici i $\mathrm{u}$ doktrinarnim djelima, tj., djelima akaida, ili u djelima islamske dijalektike, tj., djelima 'ilmul-kelama. Ehli sunnetski učenjaci su bili uvjetno prisiljeni pisati o imametu (islamskom liderstvu), njegovim uvjetima, funkcijama, itd., u djelima islamske doktrine, radi toga što 
šije ovaj problem tretiraju jednim od temeljnih pitanja svoje doktrine i zato o njemu raspravljaju u djelima koja tretiraju njihovu doktrinu.

Neki učenjaci ehli sunneta su opet, o šerijatskoj politici, raspravljali u djelima tasavvufa poput imama Gazalija. On je o politici govorio u svojoj poznatoj enciklopediji El-Ihaju' 'ulumid-din, kao i u svom poznatom doktrinarnom djelu El-Iktisadu fil-'itikadi.

Tako imam Gazali za pravnika (fekiha) veli da je znalac zakona politike i načina rješavanja međuljudskih konflikata nastalih zbog ličnih prohtjeva i strasti. Dakle, pravnik (fekih) je, po imamu Gazaliju, vladarev učitelj i savjetnik koji ga treba usmjeravati i savjetovati kako voditi i usmjeravati ljude da bi se s tim ustrojem ustrojile i stvari ovoga svijeta.

Isto tako, pravnik je vezan i za vjeru, ali ne direktno preko sebe, nego posredstvom ovog svijeta. Ovaj svijet je oranica za onaj svijet pa se radi toga vjera ne može upotpuniti bez ovoga svijeta. Vlast i vjera su blizanci. Vjera je temelj, a vladar je stražar. Ono što nema temelja je ruševina, a što nema čuvara je izgubljeno. Vlast i disciplina se ne mogu usavršiti bez vladara, a put ka discipliniranja pri rješavanju sporova je fikh. ${ }^{16}$

\section{Definicija i značenje termina politika na Zapadu}

Kako bismo dobili potpunu sliku definicije i značenja politike u islamskoj pravnoj baštini, neophodno se je ovdje, makar i načelno, osvrnuti i na definiciju i značenja politike na Zapadu.

Pri istraživanju ovoga pitanja da se zapaziti kako postoje mnogobrojne i različite definicije politike na Zapadu. Čini se da su one nastale kao produkt proporcionalnih razlika koje postoje među njihovim političkim, ekonomskim, etičkim, ideološkim i drugim pravcima, te njihovim pogledima na samu politiku.

Da bismo potvrdili spomenutu konstataciju, navest ćemo neke od definicija politike na Zapadu:

- Politika je vlast $i$ autoritet koji definiraju, tj., određuju ko će postići nešto, kada će ga postići i kako će ga postići;

\footnotetext{
${ }^{16}$ Vidi: Gazali, El-Ihja'u 'ulumid-dini, Tab'atu daril-m'arife, 1/17.
} 
- Politika je sukob radi snage i prevlasti;

- Nauka o politici počiva na proučavanju vlasti u društtvu, na proučavanju njenih temelja, načina vođenje, ciljeva i rezultata. ${ }^{17}$

Iz navedenih definicija se primjećuje da se sve fokusiraju na tri stvari: na vlast, snagu i prevlast, i da zapadna politika namjerava postići dva osnovna cilja ili temelja:

- snagu i prevlast,

- interes i korist.

S islamskoga aspekta, nema zapreke da se preko politike traži i dobije snaga $\mathrm{i}$ interes, ali pod uvjetom da ona bude samo instrument $u$ službi istine, nikako cilj sama sebi. Islamski ummet konstantno mora biti na strani snaga koje podržavaju istinu, a nikako na strani onih koji podržavaju neistinu. Historijska je činjenica da kad se snaga odvoji od istine, postaje velikom opasnošću koja prijeti slabijima i ugrožava sve nemoćne i nevine koji se ne mogu od nje zaštiti. Ta je činjenica, u stvari, Allahov sunnet (zakon) koji Kur'an otkriva u kazivanju o Adovom narodu: Ad se bez ikakvoga osnova bio na Zemlji uzoholio. 'Ko je od nas jači?'' - govorili su. A zar nisu znali da je Allah, koji ih je stvorio, jači od njih, a i znamenja naša su poricali. (Fussilet: 15)

Opći interesi i korist su, također, uvaženi i u islamskome pravu, jer Uzvišeni je i propisao sve šerijatske propise i norme, radi ovosvjetske ili onosvjetske ljudske koristi. I svako pitanje koje izađe iz okvira općih interesa i pređe u okvire štete se ni po čemu ne može smatrati Šerijatom.

Međutim, treba istaći da svi interesi i koristi, koji su u sprezi s politikom u islamu i o kojima govore Zapadnjaci, koji donose čovjeku lagodan život i omogućavaju mu da pribavi što više od ovoga svijeta, pa makar to bilo i na uštrb drugoga, ili na uštrb etičkih vrijednosti i morala, nisu po Šerijatu legalni.

Po islamu je Zakonodavac taj, koji je definirao i objasnio sve legalne interese i povezao ih sa intencijama koje se realizuju preko pet osnovnih univerzalnih ljudskih vrijednosti: preko vjere, života, potomstva, razuma i imetka.

${ }^{17}$ Sve ove definicje vidi u: Karadavi, Ed-Din ves-sijase, str. 45. 


\section{Odnos vjere i politike u percepciji islamista i sekularista}

Nakon što smo, na prethodnim stranicama, definirali vjeru i politiku sada se postavlja pitanje kakav je njihov međusobni odnos? Da li su međusobno oprečne i isključuju li se međusobno? Ili trpe, i solidarišu jedna drugu u jednoj simbiozi?

\section{Stav sekularista}

Modernisti, marksisti i sekularisti smatraju da se vjera i politika ne podudaraju i da se isključuju; vjera je oprečna politici i međusobno se ne podnose i zbog toga se nikako ne mogu usuglasiti. Prije svega izvori su im različiti, jer vjera je od Allaha a politika od čovjeka. Vjera odražava moralnu čistoću, pravdu, pravičnost i etičnost, a politika moralnu prljavštinu, varanje, licemjernost i obmanu. Cilj vjere je onaj svijet, a politike ovaj. Zbog svega toga, vjeru treba ostaviti vjernicima, a politiku političarima. Dakle, sekularisti žele vjeru bez vjerozakona, obrede bez međuljudskih odnosa, vjeru bez ovoga svijeta, misiju bez države i istinu bez snage. Njihova percepcija vjere je eksplicirala određene idejne i praktične posljedice koje su potom uzeli za temelje svoje vjerske vizije. Od kojih su:

1. Negiranje sveobuhvatnost islama, neupitne stvari kod muslimana;

2. Odvajanje vjere od politike i politike od vjere širenjem parole: Nema vjere u politici niti politike u vjeri;

3. Klevetanje onih koji pozivaju da se uvede Šerijat da su protagonisti političkog islama;

4. Vjerovanje da vjera ograničava politiku sa svojim bukvalnim značenjem tekstova, ne osvrćući se na novonastale opće interese uslijed čega muslimanima poništava mnoge interese;

5. Tvrdnja da se, po prirodi, politika mijenja i napreduje kao i svaka ovosvjetska stvar, dok je vjera po prirodi nepromjenljiva $\mathrm{i}$ konzervativna, te joj je inovativnost strana. 


\section{Negiranje sveobuhvatnosti islama}

Pitanje sveobuhvatnosti islama je neupitno kod islamskih učenjaka i muslimana. Svi oni, a posebno oni koji su reformatorski nastrojeni, tvrde da je islam sveobuhvatan sistem života, da sadržava doktrinu i vjerozakon, da je misija i država i da je vjera i politika. Spomenuto nisu samo deklarativno zagovarali, nego su ga praktično i primjenjivali radi čega su se u svom životu izlagali mnogim iskušenjima i opasnostima. Sve su to činili isključivo samo radi tri razloga:

1. Radi toga što je islam svojim normama i propisima normirao sve segmente ljudskog života: materijalni, duhovni, individualnu i kolektivnu. Mi tebi objavljujemo Knjigu kao objašnjenje za sve, i kao uputu i milost, i radosnu vijest za one koji jedino u Njega vjeruj; (EnNahl: 89)

2. Radi toga što islam ne priznaje selektivno prihvatanje svojih normi i propisa. Kur'an je jasno osudio Jevreje zbog takvog ponašanja prema Allahovom vjerozakonu i rekao: Kako to da u jedan dio Knjige vjerujete, a drugi odbacujete?! Onoga od vas koji čini tako stići će na ovome svijetu poniženje, a na Sudnjem danu biće stavljen na muke najteže. A Allah motri na ono što radite; (El-Bekare: 85)

Uzvišeni se obraća Poslaniku, a. s., govoreći mu: I sudi im prema onome što Allah objavljuje, $i$ ne povodi se za prohtjevima njihovim, $i$ čuvaj ih se da te ne odvrate od nečega što ti Allah objavljuje. (El-Maide: 49) Ovdje Uzvišeni upozorava Poslanika, a. s., na nemuslimane da ih se pripazi, te da ga ne odvrate od nekih islamskih propisa. Upozorenje Poslaniku od strane Allaha, dž. š., jeste u stvari, upozorenje svima onima koji ga slijede do Sudnjega dana, a posebno onima koji su na sebe preuzeli voditi brigu o ummetu.

U biti, islam cjelokupnom sistemu života i društva daje svoje slatke plodove samo onda, kada se uzme i primjeni u cijelosti. Svako njegovo parčanje i selektivno primjenjivanje ne može dovesti do željenih rezultata;

3. Radi toga što sam život ne prihvata biti parcijaliziran, niti se dijeliti. Isti je slučaj i sa čovjekom. Nemoguće je, npr., da ljudski život bude napredan i normalan ako islam preuzme samo brigu o džamijama i tekijama, a ostale segmente života zanemari i prepusti svjetovnim 
zakonima. Prema tome, neprihvatljivo je da islamu pripadne samo briga o džamijama, a sekularizmu o školama, univerzitetima, sudnicama, medijima, trgovima, ulicama, tj., o cijelom životu. Isto je tako nemoguće da čovjek bude dobar ako samo njegov duhovni odgoj preuzme, npr., vjera, a tjelesni, intelektualni i sentimentalni laička država. Dakle, nema dijeljenja ni kod čovjeka, a niti u njegovome životu. Čovjek je jedan, sa svojim duhovnim i tjelesnim osobinama, kao i život. Ni čovjek, ni život se ne dijele, u smislu da čovjekova duhovna strana nema nikakve veze sa materijalnom i obrnuto.

\section{Odvajanje vjere od politika}

Prvi korak kojeg su sekularisti poduzeli na putu izgradnje odnosa između vjere i politike, jeste taj da su potpuno odvojili politiku od vjere i vjeru od politike. Nakon toga su počeli širiti i propagirati poznatu klauzu da nema vjere u politici, a niti politike u vjeri. Stvar se nije zaustavila samo na tome, nego se zahtjeva i traži da se vjera potpuno odvoji od cjelokupnog života i ograniči na ljudsko srce. Ako bi joj se šta više dozvolilo od toga, onda to treba biti u okvirima bogomolja i ne smije da izađe iz njih. Ovakav stav zastupaju protagonisti ekstremnog sekularizma.

\section{Kritički osvrt na izreku da nema vjere u politici}

Odmah na početku treba razjasniti šta znači ova izreka? Da li se njome aludira na to da politika nema vjere $\mathrm{i}$ da je zbog toga oslobođena moralnih vrijednosti i vjerskih pravila? Ako je odgovor pozitivan, $\mathrm{u}$ tome slučaju politika predstavlja puki pragmatizam, jer na prvo mjesto stavlja samo interes ma gdje i kakav bio: materijalni, partijski, nacionalni, ovosvjetski, itd., vjerujući, pri tome, da je ovosvjetska materijalna koristi iznad vjere i njenih načela, a da Božije naredbe i zabrane nemaju mjesta u svijetu politike. Ovakva politika je, u stvari makijavelistička, politika koja potiskuje moral iz sfere politike, politika u kojoj cilj opravdava sredstvo. Takva politika je u stvari sredstvo preko kojega nasilnici i tirani opravdavaju svoja nedjela i zločine, počinjene nad svojim narodima - naročito nad svojim neistomišljenicima. 
Međutim, treba se zapitati i promisliti. Da li ovakvu politiku želi čovječanstvo? I da li će ovakva politika popraviti čovječanstvo, spasiti ga i dovesti do sreće?

Politika, povezana s vjerom, dobiva nove dimenzije i značenja. Ona tada odražava pravdu i ravnopravnost među ljudima, trijumf potlačenih nad njihovim tlačiteljima, davanje svim ljudima istih životnih prilika i zaštitu slabijih kategorija društva poput: jetima, siromaha, nevoljnika, itd., kao i zaštitu osnovnih ljudskih prava. Dakle, ulazak vjere u politiku nije, kako misle materijalisti i sekularisti, zlo za politiku kao i za samu vjeru. Prava vjera kada uđe u politiku, zauzima funkciju usmjerivača ka dobru, upućivača ka istini i zaštitnika od zablude i stranputice.

Vjera ne priznaje nasilje, ne zanemaruju greške, niti prešućuje stranputice. Ne priznaje dominaciju jakih nad slabima, niti prihvata da se sankcionira mali lopov a poštiva i uvažava veliki. Ulaskom u politiku vjera će je bez sumnje usmjeriti ka uzvišenim životnim i ljudskim ciljevima poput monoteizma, moralnog čišćenja i uzdizanja ljudske duše, tolerancije, pravičnih stvari, realizacije Allahovih intencija zbog kojih je stvorio ljude, pokornosti Allahu, ljudskome namjesništvu na Zemlji, njenoj izgradnji i obnavljanju preko istine $\mathrm{i}$ pravde, kao i harmonizaciji porodice, solidarizaciji zajednice, sinhronizaciji ummeta i suradnji čovječanstva. Pored toga što će vjera usmjeriti politiku ka najuzvišenijim ciljevima i najbitnijim vrijednostima, uputit će je, također, i ka najispravnijim programima preko kojih se ostvaruju ti ciljevi i na taj način će oni postati stvarnost na Zemlji koju će ljudi istinski živjeti, a ne samo deklarativno propovijedati.

Vjera $\mathrm{u}$ isto vrijeme daruje političarima stimulacije koje ih stimuliraju ka dobru, zaustavljaju ih kod istine, ohrabruju ih stati uz plemenitost, pomažu potrebnoga i osnažuju slaboga, podržavaju obespravljenoga protiv nasilnika i na taj način ga odvraćaju od nasilja. Pomozi svom bratu bi on nasilnik ili obespravljen. 'Allahov Poslaniče, pomoći obespravljenog je logično, ali kako pomoći nasilniku?', upitali su. Rekao je: 'Spriječi ga od nasilja i eto to će mu biti pomoć. ${ }^{18}$

\footnotetext{
${ }^{18}$ Bilježi ga Buharija u Mezalimima (2444) od Enesa, i Ahmed u Musnedu (11994).
} 
Vjera, također, daje političaru živu savjest koja ga odvraća od: jedenja haram imovine, legalizacije harama, prisvajanja državne imovine putem mita i korupcije, poklona ili bilo kakvih drugih malverzacija. Vjera je ta koja podstiče vladara da motivira podanike da ga pozitivno kritikuju i ukazuje na pogreške: Ako pogriješim ispravite me.$^{19}$ Ko od vas vidi pogreške neka ih ispravi. ${ }^{20}$

Prema tome, odvajanje vjere od politike značilo bi udaljavanje politike od dobra, prevencije zla, faktora dobročinstva i bogobojaznosti, te njeno prepuštanje i fokusiranje na grijeh, nepravdu i neprijateljstvo. Muslimani, kada su konzumirali zajedno svoju politiku i vjeru, bili su svjetski lideri u svim segmentima ljudskoga života.

Uspostavili su državu pravde i dobročinstva i pronijeli po cijelom svijetu civilizaciju znanja i imana i to pod zastavom Kur'ana. To je bilo, bez sumnje, zlatno doba njihove civilizacije. Danas takav model života žive Jevreji. Jasno se zna i vidi koliko je vjera imala utjecaja i koliko su je upregli kod osnivanja svoje nacionalne države, a isto to čine i neki američki predsjednici i predsjednici drugih svjetskih sila. Tako je mlađi Buš, za vrijeme svoga mandata, otvoreno izjavljivao kako mu je njegov bog naredio da zaratuje u Iraku i Afganistanu. Dokaz ovome je i postojanje, u mnogim evropskim zemljama, kršćanskih stranaka koje su legalne i legalno učestvuju na izborima, te u kreiranju nacionalne politike svojih zemalja, dok su neke čak bile ili su na vlasti.

Radi čega se onda samo od muslimana traži odvajanje politike od vjere ili vjere od politike? Najvjerovatnije samo radi toga da se oslabe i odvoje od izvora njihove snage, kako bi ostali nezaštićeni i nemoćni.

Svi su islamski mislioci suglasni, da povezivanje vlasti ili države s vjerom donosi svo dobro i snagu takvoj državi. Ibn-Haldun, kada je govorio o vrstama država, jasno je rekao da je svjetovna i vjerska država bolja od samo svjetovne države i takva država, po

\footnotetext{
${ }^{19}$ Dio hutbe koju je održao Ebu-Bekr nakon što je preuzeo vođstvo nad muslimana. Bilježi ga Abdurrezzak, u Musannefu, 11/336, Ibn-S'ad u Tabekatima, 3/183.

${ }^{20}$ Ibn-Ebu-Šejbe, El-Musannef, Kitabuz-zuhd.
} 
njemu, jeste idealna država. Dakle, on priznaje neupitan utjecaj vjere u društvenom i ostalim vidovima života. ${ }^{21}$

\section{Šta znači ta klauza da nema politike u vjeri}

Ako se pod ovom klauzom misli da se vjera apsolutno ne zanima za politiku ljudi, niti se uopće opterećuje $\mathrm{s}$ njihovim svakodnevnim životnim problemima i međusobnim odnosima, onda je takva konstatacija netačna.

Svaka vjera ima svoje stavove i naputke o spomenutim pitanjima. Negdje su oni detaljniji, a negdje koncizniji. Islam o njima ima najdužu elaboraciju. O spomenutim pitanjima u Kur'anu i sunnetu postoje mnogobrojni tekstovi, kao i pravna tradicija, pravne škole i njihova različitost $u$ poimanju, shvatanju i rješavanju istih problema. Najduži ajet u Kur'anu je ajet koji se bavi ovosvjetskim pitanjima. To je 282. ajet sure El-Bekare, u kome se traži zapisivanje i parafiranje dugova.

Isto tako, u Kur'anu postoji na stotine ajeta koji govore o pravnim normama i propisima. Kroz cijelu historiju ljudskoga roda su sljedbenici svih vjera, na bilo koji način, učestvovali u kreiranju svoga političkoga života. Čak i crkva koja zastupa ideju da se caru da carevo a Bogu Božje, nije postupila po bukvalnom značenju ove izreke, nego je s vremena na vrijeme pokušavala uzeti učešća u carevim pitanjima, uputiti i savjetovati cara, a možda i preuzeti vlast od njega.

\section{Vjera uvijek nije ograničena i koncentrirana samo na eshatologiju}

Ako se pažljivo promotri izreka da nema politike $u$ vjeri, niti vjere u politici, zapazit ćemo da se njeno značenje ne može odnositi na sve vjere, jer je apsolutno neprihvatljivo da sve vjere nemaju ništa sa politikom i da sve politike nemaju ništa sa vjerom.

Kur'an je eksplicitan da su se u samom Tevratu (Tori) nalazili različiti zakoni, a neki od njih su u Starom zavjetu ostali sve do danas. Neki su se odnosili na porodicu, drugi na zajednicu, treći na krivično, a četvrti na međunarodno pravo.

${ }^{21}$ Džami'atul Kuvejt, El-Mevsu'atul-'ulumis-sijasijjeti, str. 144-145. 
Islam je, također, donio mnoge moralne naredbe i zakonske propise koji se odnose na ovaj $\mathrm{i}$ onaj svijet i koji su razasuti po kur'anskim ajetima i Poslanikovim, a., s., hadisima. Takvi ajeti i hadisi se nazivaju ajeti $i$ hadisi propisa. Njih su protumačili pravnici u svojim djelima koja sadržavaju propise i načela o raznim ljudskim životnim pitanjima, porodici, zajednici, državi, itd., i to počevši od bontona obavljanja nužde, objedovanja, pa sve do osnivanja države i njenog odnosa s drugim narodima i državama.

Kako je onda, nakon svega izloženog, moguće tvrditi da nema politike u vjeri?! Kategorija zekjata one čija srca treba pridobiti, jeste u osnovi, politička kategorija. S njom u potpunosti raspolaže predsjednik države (halifa) radi pridobivanja naklonosti nekih plemena i određenih društvenih i političkih snaga, bilo da bi im omilio islam, bilo da bi uklonio zlo od muslimana, odvrativši njihove neprijatelje da ih ne ugroze. Sve se ovo pobrojano ali i drugo, želi postići davanjem zekjata. I to su prvenstveno politički ciljevi.

Moguće je, također, da musliman uđe u politiku čak i dok obavlja namaz, učeći ajete koji govore o suhoj politici, ili da dovi protiv okupatora i vladara tiranina preko kunut-dove koja je kod islamskih pravnika poznata kao kunutun-nevazil (dova za nesreće). Pod nesrećama se misli na razna iskušenja i nevolje koje pogađaju ummet poput okupacije, raznih prirodnih katastrofa, zemljotresa, itd.

\section{Politika nije uvijek samo sekularistička}

Ako se prethodno utvrdilo da vjera uvijek nije samo metafizička, onda je logično konstatirati, da ni politika nije uvijek sekularistička.

Mnoge su politike,u prošlosti zagovarale vjeru i branile je. Zbog toga su podnosile sve nedaće i poteškoće radi njenoga širenja. Najbolji je primjer za to car Konstantin, poznati rimski imperator, koji je prihvatio kršćanstvo, stao na stranu kršćanskih misionara i svom ga svojom snagom i moći širio u svojoj Imperiji.

Crkva je na Zapadu, cijeli srednji vijek, vodila glavnu politiku u zapadnim zemljama. Francuska revolucija je bila samo reakcija na crkvu i njene ljude koji su sa svojim konzervatizmom stali na put slobode i napretka, a sa svojim bajkama i iluzijama na put znanja. 
Crkva je tada stala zajedno s vladarima protiv naroda, a sa feudalcima protiv seljaka. Zbog svega toga, razjarene narodne mase su se digle protiv njih uzvikujući: Vješajte posljednjeg kralja sa crijevima zadnjeg svećenika!

$\mathrm{U}$ islamskome periodu, posebno $\mathrm{u}$ periodu pravednih halifa, politika je, također, bila u službi vjere. Vjera je bila glavni usmjerivač intelektualne misli, pokretač senzibilnosti i glavni djelotvorni faktor morala. Načelno se može kazati, da je ovakav odnos politike i vjere bio i tokom cijelog islamskog perioda vladavine $s$ neznatnim zanemarivanjem vjere $\mathrm{u}$ korist politike u nekim periodima. No, bez sumnje se sa sigurnošću može tvrditi da vjera, tj., islam, u tom periodu nikada nije potpuno potisnuta, niti je politici prepušteno da radi šta hoće i vlada nad kime hoće. Islam je, tokom cijele svoje historije, bio temelj sudstva u sudovima, decizija među narodom i obrazovanjem $u$ obdaništima, školama i univerzitetima. ${ }^{22}$

Spomenuti odnos između vjere i politike ni danas u savremenom svijetu nije nepoznat i neuobičajen trend. Vjera je glavni pokretač politike i kreator državne strategije kod danas vodećih demokratskih zemalja, i pored toga što to njihove službene politike negiraju i ne priznaju. Bivši američki predsjednik, Buš, i njegova partija, te cionistička država Izrael su najveći dokazi koji to potvrđuju.

Ovo je bez sumnje najveći protuargument onima, koji tvrde da su sve politike sekularističke i da vjera nema udjela ni u jednoj od njih.

\section{Politički islam}

Od izreka, kojima sekularisti i modernisti žele ocrniti islam, jeste i sintagma politički islam. Ona je, u stvari, potpuno strana islamskoj kulturi i civilizaciji. Putem nje aludiraju na islam koji se zanima za probleme islamskoga ummeta, njegove unutrašnje i vanjske odnose, rad na njegovom oslobođenju od svake strane vlasti koja vlada muslimanima i upravlja kako hoće njihovim materijalnim i duhovnim pitanjima, i na islam koji radi na oslobađanju islamskoga svijeta od svih kulturnih, socijalnih i pravnih zapadno-kolonijalističkih

${ }^{22}$ Karadavi, Tarihuna el-muftera 'alejhi, Daruš-šuruk, str. 25-32. 
natruha, kako bi se iznova muslimani vratili i primijenili Allahov zakon u svim segmentima svog života.

\section{Politički islam je neprihvatljiva i pogrešna konstatacija}

Ovu sintagmu su izmislili oni, koji nisu dobronamjerni prema islamu. Cilj im je bio podijeliti islam i pocijepati ga u skladu s različitim podjelama i rezonima koje su izmislili. Oni smatraju, da danas ne postoji jedan islam, onakav kakav ga je Uzvišeni i objavio, nego da postoje mnogi i različiti islami prema njihovim promišljanjima i rezonima.

Takvi ponekad, dijele islam po geografskim obzirima i tvrde da postoji azijski, afrički, američki i evropski islam. Drugi put ga dijele na osnovu historijskih perioda, pa vele da imamo poslanički islam, islam pravednih halifa, emevijski islam, abasijski islam, osmanski islam, savremeni islam, itd. Ponekad ga opet dijele na osnovu nacija, pa kažu da postoje arapski, indijski, turski, malezijski i drugi nacionalni islami. Ponekad ga dijele na osnovu mezheba, pa vele da postoji sunijski i šijski islam. Ponekad ga opet dijele po savremenim osnovama, pa vele da imamo revolucionarni, radikalni, klasični, desni, lijevi, nazadni i tolerantni islam. I na kraju su ga podijelili na politički, duhovni, savremeni i božanski islam - a niko ne zna kako će ga, i na koje načine, dijeliti u budućnosti.

\section{Spomenute podjele islama su neprihvatljive}

Sve navedene podjele za muslimane su neprihvatljive, jer postoji samo jedan islam, a to je islam Kur'ana i sunneta. Islam kojega su prihvatile, razumjele, primijenile $\mathrm{i}$ prenijele najbolje generacije: ashabi, tabi'ini i njihovi sljedbenici. To je jedini ispravan islam koji je bio prije bilo kakvih podjela.

\section{Islam može biti samo politički i nikakav drugačiji}

Pravi islam, islam kakvim ga je Allah propisao i objavio, može biti samo politički. Kada se odvoji politika od islama, onda to postaje sasvim druga vjera. Moguće je da on tada postane budizam, kršćanstvo, itd., ali ni u kome slučaju to više ne može biti islam i to radi dva razloga: 
1. Radi toga što islam svojim učenjem usmjerava cijeli ljudski život. On ima jasan stav i odgovor na mnoga pitanja koja se smatraju temeljima politike. Islam nije samo puka veza između čovjeka i njegova Gospodara, niti je to vjera koja nema veze sa uređenjem života, niti sa upravljanjem društvom i državom. Po svojim normama i propisima, islam je cjelokupan sistem života. Čak ni njegovo obredoslovlje nije daleko od politike. Muslimani su saglasni da onaj ko ne klanja, ne daje zekjat, javno ne posti i zanemaruje odlazak na hadždž, zaslužuje fiksnu ili diskrecionu kaznu po Šerijatu.

Ponekad takvo ponašanje nalaže i objavljivanje rata, kao što je bio slučaj za vrijeme Ebu-Bekra, r. a., protiv onih koji odbiju dati zekjat. Monoteizam je, u biti, revolucija za ostvarenja slobode, jednakosti i ljudskoga bratstva, kako ljudi jedni druge ne bi obožavali i robovali;

2. Radi toga što ličnost muslimana može biti samo politička. Islam je formirao ličnost muslimana kroz svoju doktrinu, vjerozakon, obrede i moralni odgoj, kako bi mogao biti prvenstveno politička ličnost. Musliman može imati apolitičnu ličnost samo ako pogrešno razumije islam, ili ako ga pogrešno primjenjuje.

Islam je svakog svog sljedbenika zadužio sa jednom temeljnom obligatnom vjerskom dužnošću koja se zove naređivanje dobra a odvraćanje od zla (el-emru bil-m'arufi ven-nehju 'anil-munkeri). Kolika je njena važnost u životu muslimana, vidi se iz jednog vjerodostojnog hadisa u kom se veli da ona predstavlja cijelu vjeru. ${ }^{23}$

Sam Poslanik, a. s., je stalno poticao na borbu protiv nereda i zla unutar islamskoga društva i takav vid borbe smatrao boljim od borbe protiv vanjskih neprijatelja. Kada je upitan o najboljoj vrsti džihada, rekao je: Najbolji džihad je istinita riječ izgovorena pred nepravednim vladarom. ${ }^{24}$ Takav vid borbe je najbolji radi toga što su unutrašnji neredi sigurnosni put za najezdu vanjskog neprijatelja.

\footnotetext{
${ }^{23}$ Ovdje se misli na hadis: Vjera je savjet. Bilježi ga Muslim u Imanu (55), Ahmed u Musnedu, (19640), Ebu-Davud u Edebu,(49449), od Temima Darija.

${ }^{24}$ Bilježi ga Ahmed u Musnedu (11035), Ebu-Davud u Melahimu (4344), Tirmizi u Fitenu (2174) i veli da je hasen garib, i Ibn-Madže u Fitenu (4011) od Se'ida elHudrije.
} 
Islam u srca svojih sljedbenika usađuje odbojnost prema nepravdi, pobunu protiv nasilnika i podstiče na borbu za spašavanje obespravljenih i potlačenih na Zemlji. A zašto se vi ne biste borili na Allahovu putu za potlačene, za muškarce $i$ žene $i$ djecu, koji uzvikuju: 'Gospodaru naš, izbavi nas iz ovog grada, čiji su stanovnici nasilnici, i Ti nam odredi zaštitnika, i Ti nam podaj onoga ko će nam pomoći! (En-Nisa: 75)

Kako god je musliman obavezan suprotstaviti se društvenom nasilju i nepravdi, isto je tako obavezan suprotstaviti se političkom, jer na kraju je sve to nasilje i nepravda, bez obzira kako se nazivali. Prešućivanje i zanemarivanje nasilja i nepravde donosi cijelom čovječanstvu kaznu i propast. Uzvišeni je rekao: I izbjegavajte ono što će dovesti do smutnje koja neće pogoditi samo one među vama koji su krivi, i znajte da Allah strašno kažnjava. (El-Enfal: 25)

Islam, također, zadužuje svakog muslimana političkim zaduženjem. To je da radi na tome da živi u državi u kojoj se vlada po Allahovoj knjizi, jer u protivnom se svrstava u neznalice. Ko umre a na vratu ne bude imao prisege umrijet će džahilijetskom smrću. ${ }^{25}$

\section{Političari uvode vjeru u politiku kada im ona zatreba}

Oni što tvrde da vjera nema veze za politikom a niti politika $\mathrm{s}$ vjerom, jesu neiskreni i nedosljedni svoje tvrdnje. Oni su prvi koji je krše i ne pridržavaju se njenih značenja. Obično kada im, npr., zatrebaju glasovi ili neka druga politička usluga odlaze u džamije, ili kod vjerskih dostojanstvenika među kojima nalaze slabe i neiskrene vjerske učenjake koje potkupljuju tražeći od njih fetve protiv onih koji se ne slažu s njihovom pogubnom ovosvjetskom i vjerski nelegalnom politikom. Prema tome, političari se konstantno obraćaju vjerskim učenjacima tražeći od njih da eksplicitno ili implicitno izdaju kakvu fetvu, koja će biti u službi njihovih političkih ciljeva i preko koje će dozvoliti što je Allah zabranio i zabraniti što je Allah dozvolio.

Oni koji nemaju dovoljno znanja o vjeri i koji su prodali ovaj svijet za vječnost obično im udovoljavaju željama, dok to oni koji su dobro upućeni u znanje odbijaju. Za one koji su Allahove poslanice

\footnotetext{
${ }^{25}$ Bilježi ga Muslim u Imaretu (185), i Bejheki u Es-Sunenul-kubra, fi Kitalil-bagj, $(8 / 156)$ od Ibn Omera.
} 
dostavljali i od Njega strahovali, i koji se nikoga, osim Allah, nisu bojali. A dovoljno je to što će se pred Allahom račun polagati! (ElAhzab: 39)

\section{Politika između vjerskog teksta i općeg interesa}

Mnogi modernisti i sekularisti tvrde, da će politika biti nefleksibilna ukoliko se dovede u spregu s vjerom, jer će je vjera ograničavati i sprečavati joj kretanja, a posebno ako se prihvati da je vjera doslovno pridržavanje partikularnih i detaljnih tekstova Kur'ana i sunneta.

Općepoznato je da se politika kreće u širokom prostoru interesa i šteta, te njihovom balansiranja kada dođu u koliziju. Isto tako, politici je vrlo često potrebno da napadne i uzmakne, da upotrijebi lukavštine i spletkarenja protiv neprijatelja, a možda toliku komotnost i popustljivost, vjera vjernicima ne može dozvoliti. Na taj način oni bivaju osuđeni na poraz od strane neprijatelja kojega ne sputavaju nikakva ograničenja, dok su muslimani, u isto vrijeme, sputani sa vjerskim naredbama i zabranama.

Zbog svega toga, po njihovom mišljenju, muslimanima je neophodno prihvatiti drugu metodologiju razumijevanja vjere. Po njima je to uvažavanje generalnih intencija vjere (el-mekasida) na uštrb parcijalnih tekstova, analogno Omerovoj metodi koji je, po njima, mnoge tekstove anulirao kako bi osigurao muslimanima neke interese. Bez toga, oni tvrde, vjera će i dalje ostati kamen spoticanja na putu politike, ili na putu savremene države.

Sav Šerijat je pravda, milost, interes i mudrost. Svaki propis koji izađe iz okvira pravde je nepravda, iz milosti je nemilost, iz samilosti je pokvarenost, iz mudrosti je besmislenost; ne smatra se šerijatskim i pored toga što je inkorporiran u njega preko posebnih tumačenja. ${ }^{26}$

Nakon toga, problem je i manjkavost u shvatanju i razumijevanju islama i Šerijata od strane samih muslimana, a ne u samome islamu. Obligatna vjerska dužnost je pozivati i tražiti da se islam i njegovi propisi pravilno shvate, a ne zahtijevati da se on skloni $\mathrm{s}$ puta kako bi politika išla slobodno ograničena samo s interesom,

\footnotetext{
${ }^{26}$ Ibnul-Kajjim, 'Ilamul-muvekki'ine, Darul-džej1, Bejrut, str. 3/3.
} 
kako to neki ljudi vide i traže. Neki ljudi gledaju na islam kao na idealizam koji nema nikakve veze sa stvarnošću i da njegovi sljedbenici, zajedno sa njim, lebde u zraku i ne spuštaju se u zemaljsku stvarnost. Međutim, to je apsolutno pogrešno poimanje islama.

Islam se, i pored svoje idealnosti, zanima i za stvarnost ljudi bez obzira kakva ona bila. Upotrebljava lukavost i taktiku, protiv onih koji ih koriste. Smatra da nužda zakon mijenja, da se u teškim vremenima dopuštaju stvari koje su zabranjene u normalnim, da poteškoća priziva olakšicu, itd.

Što se tiče intencija, one su neophodne za pravilno razumijevanje islama, ali se ne smiju uzeti kao sredstvo za poništenje tekstova, posebno ako se radi o jasnim i kategoričnim tekstovima, jer $\mathrm{u}$ takvim situacijama vjernik treba samo kazati i reći čujem $i$ pokoravam se. Kada Allah i Poslanik Njegov nešto odrede, onda ni vjernik ni vjernica nemaju pravo da po svom nahođenju postupe. (ElAhzab: 36)

\section{Balansiranje između tekstova i intencija}

Ono što treba uvijek imati na umu, kada su u pitanju šerijatske intencije $\mathrm{i}$ tekstovi, jeste neminovnost njihovoga usklađivanja, tj., neophodnost posmatranja partikularnih tekstova u svjetlu generalnih intencija. Apsolutno je neprihvatljivo poništavati jedno drugim, jer se oni upotpunjavaju a ne isključuju. ${ }^{27}$

\section{Tvrdnja da je Omer, r. a., poništio neke tekstove u ime općeg interesa}

Sekularisti u islamskome svijetu zastupaju, oko pitanja šerijatskih intencija, školu koja se zalaže za anuliranje parcijalnih tekstova $\mathrm{u}$ korist generalnih intencija. Svoj stav opravdavaju tvrdnjama da je Omer el-Hattab, r. a., poništio neke tekstove u ime općeg interesa.

27 O ovoj temi opširnije vidi: Karadavi, Mekasiduš-šeri'ati fi dav'in-nususildžuz'ijjeti, Daruš-šuruk. Ovu knjigu je preveo autor ove studije i očekuje se njeno štampanje u izdanju Centra za savremene studije u Sarajevu. 
Međutim, takve tvrdnje se, po islamskom učenju, ne mogu prihvatiti čak ni deklarativno od bilo koga ko poznaje najosnovnija načela islamskoga prava. Kako je onda moguće tvrditi i vjerovati da je to uradio jedan od najznanijih ashaba, koji je nekoliko puta svojom pronicljivošću i inteligencijom preduhitrio objavu?! Sve te tvrdnje su isključivo i samo produkt pogrešnoga rezonovanja i shvatanja Omerovih, r. a., postupaka.

Neizvršenje kazne za krađu i nedavanje zekjata onima čija srca treba pridobiti, jesu naredbe koje su neupitno eksplicitno naređene $\mathrm{u}$ Kur'anu. Pravne tekstove, koji ih naređuju, Omer, r. a., nije poništio niti derogirao, jer poslije Poslanika, a. s., nema više niko pravo na derogaciju. Sve što je Omer, r. a., učinio po ovim pitanjima je samo zaustavljanje primjene njihovih propisa radi toga što se u njegove vrijeme nisu stekli uvjeti za njihovu realizaciju, u smislu da ona ne bi dala željene rezultate, niti realizirala njihove intencije, tj., ciljeve radi kojih su i propisani. Međutim, bilo kada i bilo gdje, kada se stvore uvjeti za njihovu realizaciju, spomenute naredbe će se morati ponovo primijeniti.

\section{Nema kontradiktornosti između kategoričnog teksta i kategoričnog interesa}

Islamski učenjaci su saglasni da nema kolizije između stvarne koristi i kategoričnog teksta $\mathrm{i}$ da do takve kolizije apsolutno ne može ni doći. Hipotetički ako se i desi, neophodno ju je ukloniti posredstvom dva pravila:

1. Vjerovati da se ne radi o stvarnom nego umišljenom interesu, poput interesa koji se realizira preko dozvole kamate radi investicija stranih građana, alkohola radi promidžbe turizma, prostitucije radi neoženjenih, itd;

2. Vjerovati da se tad ne radi o kategoričkom, nego o spekulativnom pravnom tekstu. Treba istaći da su kod ovog pravila zglajzali mnogi istraživači, a posebno oni koji nisu specijalizirani u šerijatskim naukama poput eksperata pozitivnog prava, ekonomije, 
filozofije, itd., jer su mnoge tekstove koji nisu kategorički smatrali kategoričkim. ${ }^{28}$

\section{Opći interes u Šerijatu ima šire i dublje značenje od javnog interesa na Zapadu}

Neophodno je, također, istaći da opći interes, kojega namjeravaju u svojim pravnim raspravama islamski pravnici, nije identičan javnom interesu o kome raspravljaju zapadni pravnici.

Opći interes kod Zapadnjaka fokusira se prvenstveno na užitke i slasti, kako to promiču mnogi njihovi filozofi, ili na snagu i silu, kako to ističu mnogi teoretičari njihove politike, dok $u$ isto vrijeme ne posjeduju moralna pravila ili parametre kod realizacije te snage ili toga užitka. Ljudi, nacije i narodi na Zapadu se natječu u zadobivanju tih interesa, ali bez ikakvih vjerskih ili moralnih parametara.

Dakle, interes kod zapadnog čovjeka je prvenstveno materijalne, a ne duhovne, individualne, kolektivne, trenutačne ali ne i buduće, nacionalne ali ne i ljudske dimenzije, dok je interes, kojeg namjerava realizirati, očuvati i zaštiti Šerijat, mnogo obuhvatniji i širi.

Opći interes na kome počiva Šerijat i koga štiti, preko svih svojih propisa i normi, jeste interes koji je dostatan i za ovaj i za onaj svijet. On obuhvata i materiju i duh, izbalansiran je između pojedinca i zajednice, staleža i naroda, nacionalnog posebnog i općeg ljudskog, između interesa sadašnjih generacija i generacija koje će doći; pravedno je uravnotežen između ovih suprotnih i oprečnih interesa, koje mnogo puta ne može dostići i shvatit niti ljudsko znanje, niti ljudska mudrost a ni ljudska moć. Dakle, ljudi su nemoćni da shvate suštinu ovih interesa, kao i da ih međusobno pomire i dadnu po pravdi svakome njegovo pravo. Ova ljudska nemoć dolazi, po nama, zbog dva razloga:

- Zbog ograničenosti njihova razuma i znanja, ljudske stvorene i prolazne prirode, na koju neminovno vrše utjecaj vrijeme, mjesto, okruženje, genetika, itd;

${ }^{28}$ Vidi: Karadavi, Es-Sijasetuš-šer'ijjetu fi dav'in-nususiš-šeri'ati ve mekasidiha, str. 267-268. 
- Zbog utjecaja strasti i nagona na ljudski razum i srce, bez obzira da li oni imali lični, porodični, lokalni, staleški, partijski ili nacionalni karakter.

U ovom kontekstu imam Šatibi je rekao: Interese na kojima počiva ljudski život istinski zna samo njihov Stvoritelj (...) Čovjekovo znanje o njima je parcijalno a njegovo neznanje o njima je veće od znanja... $^{29}$

Dakle, istinski zaštiti sve interese cijeloga ljudskoga bića, tjelesne, individualne i kolektivne, duševne i inteligencijske, kao i interese svih staleža: bogataša, siromaha, vladara, podanika, radnika i domaćica; te interese cijeloga čovječanstva: bijelaca, crnaca, građana $i$ stranaca; pa i interese svih generacija, prisutnih i budućih - može samo Gospodar ljudi, Vladar ljudi i Bog ljudi. ${ }^{30}$

\section{Politika između nepromjenljivosti i promjenljivosti}

Sekularisti i modernisti, također, upozoravaju da bi uvođenje vjere u politiku imalo za posljedicu zaustavljanje razvoja i napretka, i totalnu stagnaciju ljudskoga života, jer je vjera po prirodi, stabilna $\mathrm{i}$ statična a život dinamičan.

Ovu svoju konstataciju potvrđuju s mnogim vjerskim tekstovima koji uče da je svaka promjena, inovacija ili obnova novotarija u vjeri. Svaka novotarija je zabluda, a svaka zabluda vodi u pakao. Radi toga se vjernici žestoko moraju suprotstaviti svim promjenama i inovacijama u vjeri.

Spomenuta tvrdnja je, sa stanovišta islamskoga učenja, paušalna i neprihvatljiva i ne može se prihvatiti zbog sljedećih razloga:

1. Zbog toga što je idžtihad u islamu i obnova vjere, stroga vjerska dužnost.

Islam zagovara idžtihad i obnovu vjere. Islamski učenjaci smatraju da idžtihad ima status kolektivnog vadžiba, u smislu da su svi muslimani obavezni iškolovati potreban broj mudžtehida i osigurati im sve potrebne uslove $\mathrm{i}$ instrumente, kako bi bili $\mathrm{u}$ mogućnosti iznaći sve odgovore i rješenja za novonastala pitanja i

\footnotetext{
29 Šatibi, El-Muvafekat, tab'atu Munir ed-dimiški, 1/243.

${ }^{30}$ Karadavi, Ed-Dinu ves-sijasetu, str. 99.
} 
slučajeve, jer u protivnom će snositi posljedice zbog neizvršenja te obaveze i biti odgovorni pred Allahom.

Poslanik, a. s., je u jednom hadisu rekao: Allah će uistinu na početku svakog stoljeća poslati ovom ummetu nekoga ko će mu obnoviti vjeru. $^{31}$ Dakle, Poslanik, a. s., je propisao obnovu vjere i pozvao ka tome, a potom nas obradovao da će svako stoljeće imati obnovitelja vjere. Tekstovi u kojima se osuđuje inovatorstvo i novotarije se odnose isključivo na doktrinu (el-'akide) i obrede (el'ibadat) a nikada na ljudski život i međuljudske odnose (el-'adat velmu'amelat);

2. Zbog toga što je imitacija u vjeri obavezna, a inovatorstvo je u svakodnevnom životu.

Ovo pravilo je veoma bitno i muslimani ga moraju shvatiti, razumjeti i primijeniti. Dakle, u vjeri se nema šta dodavati ni oduzimati, pošto ju je Allah usavršio i upotpunio još za života Poslanika, a. s. Zbog toga se njeni propisi i norme moraju slijediti, dok se u stvarima ovog svijeta mora istraživati, inovirati i otkrivati, a ne slijepo slijediti i povoditi se za drugima. Propisivanjem ovoga pravila, Allah je zaštitio Svoju vjeru od svih novotarija i inovacija koje su pretrpjele prethodne nebeske vjere $\mathrm{i}$ na taj način izgubile svoju autentičnost, jer se u njima otežalo ono što je Allah lahkim učinio, zabranilo se ono što je Allah dozvolio i dozvolilo se ono što je Allah zabranio. (...) dok su monaštvo oni sami, kao novotariju, uveli. Mi im ga nismo propisali... (El-Ahzab: 27)

Poslije toga, veoma je važno napraviti razliku između onoga što se obnavlja i onoga što se ne obnavlja u vjeri. Potom je nužno definirati šta se podrazumijeva pod obnavljanjem i njegovim dimenzijama i ko se smatra istinskim obnoviteljem vjere?

Isto tako, i u ljudskom društvu i životu treba napraviti razliku između onoga što je promjenljivo i što evaluira, i između onoga što ne podržava nikakve promjene. Na taj način bi se poštovale i cijenile

\footnotetext{
${ }^{31}$ Bilježi ga Ebu-Davud u Melahimima (4291) od Ebi Hurejre, Hakim u Mustedreku, 4/567, i nije se izjasnio, kao ni Zehebi, o njegovoj vjerodostojnosti, Taberani u ElEvsatu, 6/324. A Albani smatra da je ovaj hadis vjerodostojan, vidi: Sahihul-džami'i, (1874).
} 
nepromjenjive stvari, a segment primjenjivog ostao širom otvorenih vrata. $^{32}$

\section{Tvrdnja da je vjera statična a život dinamičan}

Cijela vjera nije nepromjenljiva, tj., statična, niti je cijeli život promjenljiv, tj., dinamičan.

U vjeri su nepromjenljivi: doktrina, obredoslovlje, moralne i etičke vrijednosti i kategorički propisi i norme. Ovi segmenti vjere predstavljaju njen nepromjenljivi dio, njenu srž i jezgro, koje nikada, $\mathrm{i}$ ni u kom slučaju, nije dozvoljeno narušiti, niti zanemariti. Ovaj dio je po svome obimu možda neznatan i mali, ali je zato neprocjenjivo vrijedan i važan.

Većina ostalih šerijatskih propisa imaju spekulativan karakter i podržavaju idžtihad, obnovu, te različita poimanja i tumačenja. U ovome segmentu vjere, idžtihad se mijenja i mijenjaju se fetve (decizije) i to s promjenom općeg interesa, vremena, mjesta, običaja $\mathrm{i}$ stanja u kome su nastale i izdane. Najveći dokaz za to su postojanje različitih pravnih škola, postojanje različitih pravnih mišljenja u jednoj pravnoj školi, postojanje različitih pravnih stavova i mišljenja po istom pitanju kod jednog pravnika itd.

Sva je ova različitost pravne baštine svesrdno prihvaćena od strane islamskih učenjaka i radi toga su oni jasno i glasno rekli, da je razilaženje učenjaka milost i olakšanje, a njihova saglasnost kategoričan dokaz. ${ }^{33}$

Islam preko svojih kategoričnih tekstova i generalnih pravila uči, da se mora praviti razlika između: intencije i sredstava, temelja i ogranaka, te generalnosti i partikularnosti. Zbog toga je neophodno da intencije, ciljevi, temelji i generalnosti Šerijata ostanu nepromjenjive, a da njegova sredstva, instrumentariji, ogranci i partikularnosti budu fleksibilni. Kada se sve ovo sazna i ima na umu, onda je nemoguće tvrditi i vjerovati da je vjera prepreka razvoju i napretku.

\footnotetext{
${ }^{32}$ Vidi: Karadavi, Min edžli sahvatin rašidetin tudžeddidud-dine ve tenhedu biddun'ja, nešr: mektebetu vehebeti bil-kahireti ve muessesetir-risaleti, Bejrut, str. 5766.

${ }^{33}$ Ibn-Kudame, El-Mugni, tab'atu hidžr, Kahire, 1/4.
} 
Isto pravilo važi i za život, jer ni on cijeli nije promjenjiv kako to neki misle. Njegova suština, bit i priroda, kao i priroda čovjeka $\mathrm{i}$ kosmosa su nepromjenjivi, a njegova stanja i pojave su samo promjenjive. Sunce, Zemlja, okeani, nebesa su ostali isti - svi oni permanentno plutaju svojim putanjama, poštuju svoje zakonitosti i služe svrsi radi koje su stvoreni. U Allahovim zakonima ti nikad nećeš naći promjene, u Allahovim zakonima ti nećeš naći odstupanja. (Fatir: 43)

Tačno je, da se kod čovjeka promijenila moć i mogućnosti, spoznaja i informacije, pa je zbog toga moćan letjeti zrakom, roniti u okenima, prelaziti za kratko vrijeme velike razdaljine, otkriti i koristi za svoje potrebe ogromna naučna saznanja itd.

Ali i pored svega toga, čovjek je po svojoj prirodi, biti i suštini i dalje ostao isti kakvim ga je prvi puta njegov Kreator i kreirao. Isto se može reći i za kosmos, zemlju i ostale dijelove prirode.

\section{Zaključna razmatranja}

Studija je u konačnici došla do sljedećih rezultata:

- Riječ islam, u islamskim izvorima, ima šire značenje od riječi vjera (ed-din);

- Termin politika nije eksplicitno upotrijebljen u islamskim izvorima, ali njegova značenja i suština su itekako zastupljeni u njima;

- Ibnul-Kajjim je prvi islamski učenjak koji je temeljito i detaljno govorio o politici, objasnio njen smisao i značenje, podijelio je na pravednu i nepravednu i ustanovio da je pravedna politika nerazdvojivi dio islama;

- Značenja politike u islamu i zapadnoj filozofiji nisu identična i podudarna, njena značenja u islamu su šira;

- Odvajanje vjere od politike i ostalih segmenata života, jeste inovacija i mezimče sekularista i modernista, čija je refleksija na međuljudske odnose i život uopće bila katastrofalna;

- Politika bez vjere je nasilje, nepravda, obmana, laž, korupcija, potlačivanje i izrabljivanje; 
- Vjera je itekako involvirana u politiku, jer skoro svaka vjera ima svoje stavove o esencijalnim pitanjima politike;

- Vjera nije uvijek ograničena samo na eshatološka pitanja, kao što ni politika nije uvijek samo sekularistička;

- Svaka savremena podjela islama, po bilo kome osnovu, jeste neprihvatljiva pošto je islam samo jedan, islam Poslanika, a. s., i prvih generacija;

- Pravi islam može biti samo politički;

- U šerijatskoj politici se mora balansirati između generalnih intencija i partikularnih tekstova;

- Omer, r. a., niti bilo ko drugi, nema pravo derogirati bilo koji propis islama;

- Omer, r. a., nije aktivirao propise nekih pravnih tekstova samo radi toga što nisu bili stvoreni uvjeti za njihovu realizaciju;

- Opći interesi o kojima govori Šerijat su širi i dublji od općih interesa o kojima govori zapadna politika;

- Većina šerijatskih propisa su dinamični, u smislu podržavanja idžtihada, a samo mali dio njih je statičan, u smislu ne podržavanja idžtihad;

- Islam nije, niti može, niti smije biti kočnica na putu razvoja i napretka ljudskog života.

\section{Literatura:}

1. Džami'atul-Kuvejt, Mevsu'atul-'ulumis-sijasijjeti, Kuvajt.

2. El-Dževzijje Ibnul-Kajjim, Et-Turukul-hukmijje, El-Mektebetul-islamijjetu, Bejrut.

3. El-Dževzijje Ibnul-Kajjim, 'Ilamul-muvekki'ine, Matbe'atu-se'ade, Egipat, naučna valorizacija Muhammed Muhjiddin Abdulhamid.

4. El-Gazali Ebu-Hamid, El-Ihja'u 'ulumid-dini, Darul-m'arife, Bejrut.

5. El-Karadavi Jusuf, Ed-Dinu ves-sijasetu, t'esilun ve reddu šubehatin, ElMedžlisul-eurubijju lil-iftai vel-buhusi.

6. El-Karadavi Jusuf, Mekasiduš-šeri'ati fi dav'in-nususil-džuz'ijjeti, Daruš-šuruk, Kairo. 
7. El-Karadavi Jusuf, Min edžli sahvatin rašidetin tudžeddidud-dine ve tenhedu biddun'ja, Mektebetu vehebeti bil-kahireti ve muessesetir-risaleti, Bejrut.

8. El-Karadavi Jusuf, Tarihuna el-muftera 'alejhi, Daruš-šuruk, Kairo.

9. El-Makdisi Ibn-Kudame, El-Mugni, Tab'atu hidžr, Kairo.

10. Eš-Šatibi Ebu-Ishak, El-Muvafekat, Tab'atu Munir ed-dimiški.

11. Vizaretul-Evkafi veš-šu'unil-islamijjeti, El-Mevsu'atul-fikhijjetul-kuvejtijje, Četvrto izdanje, 1414. H. ili 1993. god. 
Prof. dr. Sulejman Topoljak, P.H.D.

\section{RELATION OF RELIGION AND POLITICS IN THE PERCEPTION OF ISLAM AND SECULARISM}

\section{SUMMARY}

Aim of this study is to research and explore relation of religion and politics from aspect of Islam and secularism. General opinion, among the elite and common people, is that these two social categories are exclusive and impossible to integrate into one mechanism - society, in which they would act mutually and provide positive results and useful conclusions.

After thorough research, study has proven that conventional vision of relation between subject social categories is superficial and incorrect, and that the opposite thesis is correct. Study concludes that Islam and politics are inseparable social dimensions, because it is impossible to live Islam without politics, and to implement and support correct politics without the true religion.

Key words: politics, religion, Islam, political Islam, Shariah policy, secularism, secularists, modernism, modernists 
الأستاذ الدكتور سليمان توبولياك

العلاقة بين الدين والسياسة في نظر الإسلاميين والعلمانيين

\section{خلاصة البحث}

الهدف من هذه الدراسة هو التحقيق وإلقاء الضوء على العلاقة بين الدين والسياسة من حيث الإسلام والعلمانية. الرأي العام السائد في أوساط النخبة والشعب أن أن هاتين الفئتين

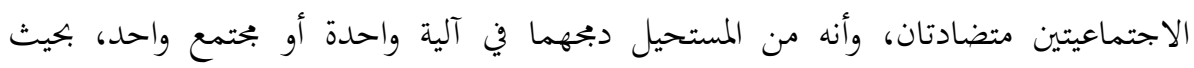
يتصرفان على نحو متبادل وتعطيان نتائج إيجابية ونقطة انطلاق مفيدة. أثبتت الدراسة بعد البحث الوافي أن الرؤية التقليدية للعلاقات الاجتماعية بين الفئات المذكورة غير صحيحة، وأن العكس هو

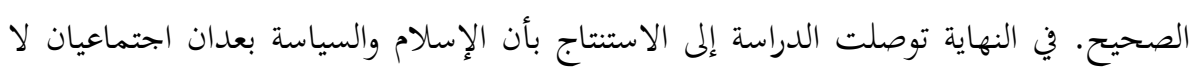
يمكن انفصالهما، وذلك لأن الاسلام يستحيل العيش على أسسه من دون السياسة وأنه يستحيل ممارسة السياسة الحقيقية من دون الإيمان الحقيقي.

الكلمات الرئيسة: السياسة، الدين، الإسلام، الإسلام السياسي، السياسة الشرعية، العلمانية، العلمانيون، الحداثة، الحداثيون. 